\title{
Davranışsal Denge Döviz Kuru Yaklaşımı ile Reel Döviz Kurlarının Yanlış Dengelenmesinin Ölçülmesi: Türkiye Örneği ${ }^{1}$
}

\author{
Sevgi Gerek ${ }^{2}$ \\ Mustafa Karabacak ${ }^{3}$
}

\begin{abstract}
Davranışsal Denge Döviz Kuru Yaklaşımı ile Reel Döviz Kurlarının Yanlış Dengelenmesinin Ölçülmesi: Türkiye Örneği

Öz

Çalışmada, 1991Q1-2014Q3 döneminde Türkiye için reel döviz kurlarının yanlış dengelenmesi, "Davranışsal Denge Döviz Kuru Modeli" ile belirlenmiştir. Davranışsal denge döviz kuru modelinden elde edilen sonuçlar, Türkiye'de ele alınan dönem boyunca genel olarak reel döviz kurlarının yanlış dengelendiğini, cari yanlış dengelenmenin boyutunun 1994 krizinde \%140'a 2001 krizinde \%195'e, toplam yanlış dengelenmenin ise 1994 krizinde \%50'ye 2001 krizinde \%125'e ulaştığını, göstermektedir. Çalışmadan elde edilen bir diğer önemli bulgu ise Türkiye'de sabit kur rejiminin uygulandığı dönemlerde, reel döviz kurlarının hem cari denge seviyesinden hem de uzun dönem denge seviyesinden ciddi ölçüde sapma gösterdiğini, esnek kur rejimine geçilmesinin ardından ise denge seviyesine yakınsadığını ortaya koymaktadır.
\end{abstract}

Anahtar Kelimeler: Davranışsal Denge Döviz Kuru Modeli, Reel Döviz Kurlarının Yanlış Dengelenmesi, Reel Döviz Kuru, Denge Reel Döviz Kuru

\author{
Measuring the Real Exchange Rate Misalignment with \\ Behavioral Equilibrium Exchange Rate Approach: The \\ Case of Turkey
}

\section{Abstract}

In this study the real exchange rate misalignment in Turkey in 1991Q1-2014Q3 period was determined by "Behavioral Equilibrium Exchange Rate Model". The results obtained from the behavioral equilibrium exchange rate model show that the real exchange rate has been misaligned in general throughout the period covered in Turkey and that the size of the current misalignment has reached to $140 \%$ in the 1994 crisis and to $195 \%$ in the 2001 crisis. And the size of total misalignment has reached to $50 \%$ in 1994 crisis and $125 \%$ in the 2001 crisis. Another important finding from the study is that the real exchange rate in Turkey is significantly misaligned from both its current and the long-run equilibrium level in the period when the fixed exchange rate regime is applied, and after reaching the flexible exchange rate regime, it converged to its equilibrium level.

Keywords: Behavioral Equilibrium Exchange Rate Model, Real Exchange Rate Misalignment, Real Exchange Rate, Equilibrium Real Exchange Rate

\section{Giriş}

Bir ülkenin dış rekabet gücünün en önemli göstergesi olan reel döviz kurları ekonomik birimlerin üretim, tüketim ve yatırım kararları üzerinde etkili olan bir değişkendir. Dolayısıyla reel döviz kurunun seviyesi politika yapıcılar açısından bir sinyal olarak algılanmakta ve ekonomi politikalarına yön vermektedir. Bununla birlikte, ülke ekonomileri hakkında sadece cari reel döviz kuru ele alınarak yapılan değerlendirmeler yeterli olmamaktadır. Bu nedenle ülke ekonomisinin dinamikleri göz önüne alınarak, denge reel döviz kurunun hesaplanması ve cari reel döviz kurunun denge değerinden ne kadar sapma gösterdiğinin de ölçülmesi gerekmektedir. Cari reel döviz kurunun denge seviyesinden kısa süreli sapmalar göstermesi doğaldır. Ancak reel döviz kurunun denge seviyesinden kalıcı olarak uzaklaşması ekonomi açısından önemli bir problemdir ve bu durum iktisat literatüründe "reel döviz kuru yanlış dengelenmesi" olarak adlandırılmaktadır.

\footnotetext{
${ }^{1}$ Bu çalışma “Uzun Dönem Reel Döviz Kurlarının Belirlenmesi ve Reel Döviz Kurlarının Yanlış Dengelenmesi: Türkiye Örneği" ismiyle tamamlanarak, 18.03.2016 tarihinde savunulan doktora tezinden türetilmiştir.

${ }^{2}$ Prof. Dr., Anadolu Üniversitesi, iktisat Fakültesi, i̇ktisat Bölünü, sgerek@anadolu.edu.tr

${ }^{3}$ Yrd. Doç. Dr., Uşak Üniversitesi, iïBF, İktisat Bölümü, mustafa.karabacak@usak.edu.tr
} 
Kalıcı yanlış dengelenmeler genellikle ekonomik istikrarı ve ekonominin büyüme performansını olumsuz etkilemektedir. Yerli para biriminin reel manada aşırı değerlenmesi, sürdürülebilir olmayan bir cari açık, artan dış borç ve spekülatif ataklara neden olabilen, tutarsız makroekonomik politikaların bir göstergesidir. Dolayısıyla yanlış dengelenmenin ölçülmesi hem ekonominin genel işleyişi açısından hem de uygulanacak iktisat politikaların başarısı açısından büyük önem arz etmektedir. 2008 küresel finansal krizin ardından yanlış dengelenmenin ölçülmesi ve giderilmesi gelişmekte olan ekonomilerin ilgi odağı haline gelmiştir. Zira krizinin ardından dünyanın önde gelen ekonomilerinin faiz oranlarını düşürerek sıfıra yaklaştırması, dünyanın geri kalanında para otoritelerinin, yanlış dengelenmenin ve özellikle aşırı değerlenmenin önüne geçmek amacıyla döviz kuru piyasalarına müdahale etmelerine neden olmuştur. Bu açıdan değerlendirildiğinde, olası yanlış dengelenmenin ölçülmesi 2000'li yılların başlarında kura dayalı bir istikrar politikası yürütürken büyük bir kriz yaşayan Türkiye ekonomisi açısından da hayati önem taşımaktadır. Ancak yanlış dengelenmenin ölçülmesi konusunda genel kabul gören tek bir yöntemden bahsetmek mümkün değildir. Yanlıs dengelenmenin ölçülmesi için öncelikle denge reel döviz kurunun belirlenmesi gerekmektedir. Zira denge reel döviz kuru gözlemlenebilen bir değişken değildir ve bir takım ekonomik veya ekonometrik modellere dayalı olarak elde edilmesi gerekmektedir. Dolayısıyla ekonomik ve ekonometrik modellerin çeşitliliğine bağlı olarak veri bir cari reel döviz kuru için farklı denge reel döviz kurları hesaplanabilmektedir.

Bu nedenle denge reel döviz kurunun hesaplanması için çok sayıda alternatif model mevcuttur. Denge reel döviz kuru modellerini temel yaklaşımlar ve yeni yaklaşımlar olarak iki ana başlık altında ele almak mümkündür. İlk olarak Temel yaklaşımlar başlığı altında, Satın Alma Gücü Paritesi ve Faiz Paritesi Teorisi gibi en temel ve en eski denge reel döviz kuru belirleme modelleri ile birlikte bu modelleri temel alan veya eleştiren Balassa-Samuelson Hipotezi, Mundell-Fleming Modeli ve Monetarist Modeller yer almaktadır. İkinci ana başlık altında ise temel yaklaşımların ampirik başarısızığı sonuncunda geliştirilen Temel Denge Döviz Kuru Modeli, Davranışsal Denge Döviz Kuru Modeli ve Döviz Kuru ile Geliştirilmiş Taylor Kuralı Modeli ile birlikte, bu modelleri mikro temellerden yoksun olması nedeniyle eleştiren ve optimizasyona dayalı modeller olan REDUX ve NATREX modelleri yer almaktadır. Türkiye'de olası yanlış dengelenmenin ölçülmesi amacıyla, bu çalışmada söz konusu alternatif modeller arasında yeni yaklaşımlardan biri olan davranışsal denge döviz kuru modeli uygulanmıştır. Bu bağlamda çalışmanın 2. Bölümünde öncelikle Clark ve MacDonald (1997, 1998, 1999 ve 2000)'ın popülerlik kazandırdığı "Davranışsal Denge Döviz Kuru Modeli" açıklanmıştır. 3. Bölümde ise Türkiye için yanlış dengelenmenin belirlenmesi amacıyla davranışsal denge döviz kuru modeli tahmin edilmiştir. Analizde 1991Q1-2014Q3 dönemini kapsayan çeyreklik veriler kullanılmış ve eşbütünleşme tekniklerinden faydalanılmıştır.

\section{Davranışsal Denge Döviz Kuru Modeli}

Gözlemlenemeyen bir değişken olan denge reel döviz kurunun ölçülmesinin güçlüğü nedeniyle, reel döviz kurlarının yanlış dengelenmesini belirlemek oldukça zor bir süreçtir. Yanlış dengelenmenin ölçülmesinde sıkça kullanılan yaklaşımlardan biri olan satın alma gücü paritesine göre, öncelikle ekonominin dengede olduğu düşünülen bir yıl seçilmekte ve bu yıl için hesaplanan reel döviz kuru, denge reel döviz kuru olarak belirlenmektedir. Yanlış dengelenme ise örneklem dönemi boyunca, reel döviz kurunun, satın alma gücü paritesi ile belirlenen denge reel döviz kurundan sapması ile ölçülmektedir. Bu yaklaşımla ilgili temel sorun ise iktisat teorisinin, dengedeki bir ekonomide dahi, denge reel döviz kurunun zaman içinde değişebileceğini öngörmesine rağmen, satın alma gücü paritesinin tek ve sabit bir denge reel döviz kuru olduğunu öne sürmesidir. Ancak daha önce de belirtildiği gibi, denge reel döviz kurlarının tanımlanması ve 
ölçülmesi konusunda, birbirinden farklı birçok yaklaşım söz konusudur. Davranışsal denge döviz kuru modelleri de herhangi bir teorik modele dayanmaksızın, reel döviz kurunu, temel makro değişkenlerin bir fonksiyonu olarak modellemektedir. Modelin "davranışsal" denge döviz kuru olarak adlandırılmasının nedeni ise modelin teorik bir modele dayanmamasından kaynaklanmaktadır.

Davranışsal Denge Döviz Kuru Modeli (Behavioral Equilibrium Exchange Rate, BEER) Clark ve MacDonald (1998)'ın çalışmalarıyla adını duyurmuştur. Ancak Edwards (1987, 1988, 1989 ve 1994) ve Elbadawi (1994)'nin çalışmaları da MacDonald (2007)'a göre BEER modeli kapsamında yer almaktadır. Bu nedenle, davranışsal denge döviz kuru modellerinin kökenlerinin bu çalışmalara dayandığını söylemek mümkündür.

Ancak Edwards (1987, 1988, 1989 ve 1994) ve Elbadawi (1994) modelleri her ne kadar davranışsal denge döviz kuru modelleri arasında yer alsa da, davranışsal denge döviz kuru modelleri Clark ve MacDonald (1997, 1998, 1999 ve 2000)'ın çalışmalarıyla şekillenmiş ve popülerlik kazanmıştır. Clark ve MacDonald modeli, reel döviz kurunun yalnızca uzun veya orta dönemli hareketlerini açıklamaya yönelik değil, zaman içindeki hareketlerini de açıklamaya yönelik bir modeldir. Dolayısıyla reel döviz kurunun kısa dönemli hareketlerini açıklamak amacıyla da kullanılabilmektedir.

Clark ve MacDonald modelinin çıkış noktası, zamana göre değişen risk primi ile geliştirilmiş, örtük olmayan reel faiz paritesi koşuludur ${ }^{4}$. Ancak risk primi ile genişletilmiş olmasına rağmen, reel döviz kurunun gelecekteki değerine yönelik beklentilerin eksikliği nedeniyle, örtük olmayan faiz paritesi koşulunu bir ampirik model olarak yorumlamak güçtür. Bu nedenle Clark ve MacDonald (1997 ve 1999) gelecek döviz kuru beklentilerinin uzun dönem temel makro değişkenlerle ilişkili olduğu varsayımında bulunmuştur:

$$
E_{t}\left[\Delta e_{t+k}\right]=-\left(i-i^{*}\right)+\pi_{t}
$$

Eşitlik (1)'de $E_{t}[$.$] , beklenti operatörü olmak üzere, i$, nominal faiz oranını, $\pi_{t}=\lambda_{t}+k$, zaman göre değişen $\lambda_{t}$ bileşeni ile genişletilmiş risk primini ve $e$, yine nominal döviz kurunun logaritmasını ifade etmektedir. Clark ve MacDonald (1998) modelinde nominal döviz kuru ise bir birim yerli paranın yabancı para cinsinden değeri olarak tanımlanmıştır (Örn: yerli para TL ve yabancı para birimi \$ iken; $1 \mathrm{TL}=0.37 \$)$. Eşitlik (1)'den beklenen enflasyon farkları $E_{t}\left(\Delta p_{t+k}-\Delta p_{t+k}{ }^{*}\right)$ çıkarıldığında ise reel faiz paritesi eşitliğine ulaşılmaktadır:

$$
q_{t}=E_{t}\left[q_{t+k}\right]+\left(r_{t}-r_{t}^{*}\right)-\pi_{t}
$$

$r_{t}=i_{t}-E(\Delta p+k)$ exante reel faiz oranını ifade etmek üzere, eşitlik (2) cari denge döviz kurunun, $t+k$ periyodu için reel döviz kuru beklentileri, $t+k$ vadeli reel faiz oranı farkı ve risk primi tarafından belirlendiğini ifade etmektedir. Risk priminin eşitlik (2)'de negatif işaretli olarak yer almasının nedeni, risk primindeki bir artışın reel döviz kurunda (modelin yapısı gereği, reel bir değer artışı beklentisi yaratacak) bir değer kaybıyla sonuçlanmasıdır. Clark ve MacDonald

\footnotetext{
${ }^{4}$ Ampirik analizlerde risk primi genellikle, kamu iç borç stokunun ya da kamu dış borç stokunun GSYiH'e oranı ile temsil edilmektedir.
} 
(1998) zamana göre değişen risk primi bileşeninin $\left(\lambda_{t}\right)$ ise yurtiçi ve yurtdışı kamu borç stoklarının (sırasıyla $g d b_{t}^{+}$ve $g d b_{t}^{*}$ ) nispi oranının bir fonksiyonu olduğunu varsaymışlardır.

$$
\lambda_{t}=g\left(g d b_{t}^{+} / g d b_{t}^{*}\right)
$$

Bu nedenle, ödenmemiş yurtiçi borçların yurtdışı borçlara nispi oranındaki bir artış, yurtiçi risk priminde bir artışa neden olacaktır. Bu durum ise cari denge reel döviz kurunda bir değer kaybına neden olacaktır. Daha önce de bahsedildiği gibi, bu eşitliği daha işlevsel hale getirmek için Clark ve MacDonald (1998) (gözlemlenemeyen) gelecek döviz kuru beklentilerinin , $E_{t}\left[q_{t+k}\right]$, uzun dönem temel makro değişkenlerle, $Z_{t 1}$, ilişkili olduğu varsayımında bulunmuştur. Dolayısıyla uzun dönem denge reel döviz kuru eşitlik (4)'teki gibi ifade edilmiştir:

$$
\hat{q}_{t}=E_{t}\left[q_{t+k}\right]=E_{t}\left[\beta_{t}^{\prime} Z_{1 t}\right]=\beta_{t}^{\prime} Z_{1 t}
$$

Eşitlik (4)'ten anlaşılacağı gibi uzun dönem reel döviz kuru yalnızca uzun dönem temel makroekonomik değişkenler, $\beta_{t} Z_{1 t}$, tarafından belirlenmektedir. $Z_{1 t}$ vektörünü oluşturan değişkenler ise, dış ticaret hadleri (tot), Balassa-Samuelson etkisi (tnt) ve net dış varlıklardır ( $n f a)$. Dolayısıyla Clark ve Macdonald modeline göre, uzun dönem reel döviz kuru, bu üç temel makroekonomik değişkenin bir fonksiyonudur:

$$
\begin{array}{r}
\hat{q}_{t}=f\left(\text { tot }_{t}, \text { tnt }_{t}, n f a_{t}\right) \\
(+)(+)(+)
\end{array}
$$

Orijinal Clark ve MacDonald modeli, aslında herhangi bir spesifik döviz kuru modeline dayanmamaktadır. Bu nedenle, genellikle denge döviz kurlarını modellemek için kullanılan oldukça genel bir yaklaşım olarak görülmektedir (Macdonald ve Dias, 2007: 4). BEER modeli uygulamalarının odak noktası, genel olarak, sıfıra eşit cari işlemler hesabı koşuluna dayanmaktadır. BEER modeli, döviz kurundaki sistematik hareketleri ve temel makro değişkenlerden kaynaklanan hareketleri yakalamada oldukça başarılı bir yaklaşımdır. Ayrıca çözümlenmesi son derece zor olan diğer döviz kuru modellerinin ${ }^{5}$ aksine, denge döviz kurunun çözümlenebilmesi için uygulanabilirliği daha yüksek bir yaklaşım olarak görülmektedir. Daha da önemlisi, BEER modelleri sürdürülebilirlik gibi herhangi bir normatif unsurdan bağımsız bir şekilde yanlış dengelenmenin ölçülmesine olanak tanımaktadır6.

BEER tahmin süreci ise genellikle 4 aşamada gerçekleşmektedir. Illk aşamada, reel döviz kuru ve temel makroekonomik değişkenler ve kısa dönem değişkenler arasındaki uzun ve kısa dönem ilişkileri vektör hata düzeltme modeli (Vector Error Correction, VECM) ile tahmin edilmektedir. İkinci aşamada ise cari yanlış dengelenme hesaplanmaktadır. Bu aşamada kısa dönem değişkenler sıfır varsayılıp birinci aşamada tahmin edilen temel makroekonomik değişkenlerin gerçek değerleri, tahmin edilen eşitlikte yerine koyulmaktadır. Cari yanlış dengelenme reel döviz kuru-

\footnotetext{
${ }^{5}$ Doğal denge döviz kuru modeli, Temel denge döviz kuru modeli ve Redux modelleri, BEER modellerine göre teorik altyapısı daha güçlü olmakla birlikte, çözümlenmesi daha karmaşık modellerdir.

${ }^{6}$ Williamson (1983) tarafından geliştirilen temel denge döviz kuru modeli, içsel ve dışsal dengeyle tutarlı bir denge reel döviz kuru belirlemeyi amaçlamaktadır. Bu bağlamda içsel dengenin sağlanmış olması için mevcut üretimin potansiyel üretime eşit olduğu ve dolayısıyla fiyatların istikrarlı olduğu durumu ifade etmekteyken, dışsal denge cari hesap ile net sabit sermaye girişlerinin toplamı olarak ifade edilmektedir. Dışsal dengenin sağlanabilmesi için minimum koşul ise cari hesap dengesinin sürdürülebilir seviyede olmasıdır.
} 
nun elde edilen uyumlu değerleri (fitted value) ve gerçek değerleri arasındaki fark ile ölçülmektedir. Üçüncü aşamada ise temel makro değişkenlerin uzun dönem, ya da sürdürülebilir değerleri elde edilmektedir. Değişkenlerin uzun dönem veya sürdürülebilir değerlerini elde etmek için seriler, Hodrick-Prescot filtresi ya da Beveridge-Nelson ayrıştırması gibi yöntemler kullanılarak kalıcı ve geçici bileşenlere ayrılmaktadır. Dördüncü ve son aşamada ise toplam yanlış dengelenme ölçülmektedir. Bu aşamada, kısa dönem değişkenler yine sıfırlanarak, temel makro değişkenlerin uzun dönem değerleri tahmin edilen eşitlikte yerine konmaktadır. Sonuç olarak, reel döviz kurunun bu eşitlikten elde edilen uyumlu değerleri ile gerçek değerleri arasındaki fark ise toplam yanlış dengelenmeyi verecektir (MacDonald ve Dias, 2007: 9).

\section{Davranışsal Denge Döviz Kuru Modeli ile Türkiye için Yanlış Dengelenmenin Ölçülmesi}

BEER yaklaşımı denge reel döviz kurunun, temel makroekonomik değişkenlerin bir fonksiyonu olduğunu savunan yaklaşımlardan biridir. Dolayısıyla BEER modelinde, satın alma gücü paritesinden farklı olarak, reel döviz kurunun denge seviyesi, temel makro değişkenlerin cari ve uzun dönem denge seviyelerine göre değişmektedir. Ayrıca yine satın alma gücü paritesinden farklı olarak, yanlış dengelenmenin boyutunun ölçülmesine de olanak tanımaktadır. Bu nedenle, Türkiye için denge reel döviz kurunun elde edilmesi ve yanlış dengelenmenin ölçülmesi amacıyla BEER modeli tahmin edilmiştir.

Analizde kullanılan tüm veriler 1991Q1-2014Q3 dönemini kapsayan çeyreklik verilerdir. Veriler OECD, TCMB, IMF ve FED'in istatistik veri tabanlarından elde edilmiştir. Analizde kullanılan reel döviz kuru (Q) serisi TCMB elektronik veri dağıtım sisteminden elde edilen, nominal \$/TL kuru (E) ile OECD internet sitesinden elde edilen, 2010 baz yıllı, yurtiçi ve yurtdışı tüketici fiyat endeksleri (TÜFE) aracılı̆̆ıyla eşitlik (6)'daki gibi hesaplanmıştır. Nominal döviz kuru (E) bir birim yabancı paranın yerli para birimi cinsinden değerini ifade ederken, eşitlik (3.9) ile hesaplanan reel döviz kurundaki artışlar, TL'nin reel olarak değer kaybettiğini, azalışlar ise TL'nin reel olarak değer kazandığını ifade etmektedir.

$$
Q=\frac{E \times P^{*}}{P}
$$

Eşitlik (6)'da $E$ bir birim yabancı paranın, yerli para birimi cinsinden değerini ifade etmekte-

dir. $P$ ve $P^{*}$ ise sırasıyla yurtiçi ve yurtdışı fiyat seviyelerini ifade etmektedir. Yurtiçi ve yurtdışı fiyat seviyelerini temsilen ise daha önce belirtildiği gibi TÜFE serileri kullanılmıştır. Analizde Clark ve MacDoland (1998) ve Clark ve Macdonald (2000)'ın BEER yaklaşımı benimsenmiştir. Daha önce detaylı bir şekilde açıklanan BEER modeli basitçe eşitlik (7)'deki gibi ifade edilebilmektedir.

$$
\hat{q}_{t}=f\left(\text { tot }_{t}, \text { tnt }_{t}, n f a_{t}, g d b / g d b^{*} r-r^{*}\right)
$$

Eşitlik (7)'de tot $_{t}{ }_{t}$ ve tnt $_{t}{ }_{t}$ sırasıyla nispi dış ticaret hadlerini ve nispi verimliliği ifade etmektedir. Her iki ülke için dış ticaret hadleri, ihracat fiyat endeksinin ithalat fiyat endeksine oranı şeklinde ifade edilmekte, nispi dış ticaret hadleri ise yurtiçi dış ticaret hadlerinin, yurtdışı ticaret hadlerine oranı şeklinde elde edilmektedir. Nispi dış ticaret hadleri serisinin hesaplanmasında kullanılan veriler IFS veri tabanından elde edilmiştir. Nispi verimliliğin hesaplanması için ise dış ticarete konu olan malların fiyatlarını temsilen TÜFE, dış ticarete konu olmayan malların fiyatIarını temsilen ÜFE serileri kullanılmıştır. Verimlilik her iki ülke için TÜFE/ÜFE şeklinde hesaplanırken, nispi verimlilik, yurtiçi verimliğin yurtdışı verimliliğe oranı ile ifade edilmiştir. Analizde kullanılan $n f a$ serisi, yurtiçi net dış varlıkları ifade etmek üzere, TCMB analitik bilançosunda yer alan dış varlıklardan, dış yükümlülüklerin çıkarılıp GSYiH serisine bölünmesiyle elde edilmiştir. 
Nispi toplam kamu borcunu ifade eden $g d b / g d b^{*}$ oranı modele risk faktörü olarak dâhil edilmiştir ve söz konusu seriler TCMB ve FED veri tabanlarından elde edilmiştir. Reel faiz oranlarına dair veriler ise IFS veri tabanından elde edilmiştir. ABD nominal faiz oranını temsilen hazine bonosu faiz oranı ve Türkiye nominal faiz oranlarını temsilen mevduat faiz oranları kullanılmıştır. Her iki ülke için reel faiz oranları, nominal faiz oranlarından tüketici enflasyonundaki yüzde değişim çıkarılarak hesaplanmıştır. Analizde $q$, tot $^{\prime}{ }_{t}$ ve tnt $_{t}{ }_{t}$ değişkenleri logaritmik seviyeleri ile kullanılmıştır.

Tablo 1: BEER Modelinde Kullanılan Değişkenlerin Işsaretlerine Dair Beklentiler

\begin{tabular}{|c|c|c|c|c|}
\hline$r-r^{*}$ & tot & tnt & $n f a^{\prime}$ & $g d b^{\prime}$ \\
\hline$+/-$ & - & - & - & $+/-$ \\
\hline
\end{tabular}

Daha önce de belirtildiği gibi, eşitlik (6) yardımıyla hesaplanan reel döviz kurundaki artışlar TL'nin reel olarak değer kaybettiğini, azalışlar ise reel olarak değer kazandığını ifade etmektedir. Modelde yer alan değişkenlerin TL'nin değerini ise Tablo 1'deki gibi etkilemesi beklenmektedir (Çulha vd., 2008);

- Faiz farklarının reel döviz kuru üzerindeki etkisi net değildir. Örtük olmayan faiz paritesi teorisine göre, yüksek faiz oranına sahip ülkenin para birimi, arbitraj imkânlarının ortadan kalkması için değer kaybetmelidir. Ancak yüksek faiz oranları sermaye akımlarını uyararak para biriminin değer kazanmasına da neden olabilmektedir.

- Dış ticaret hadlerindeki bir iyileşmenin yerli paranın değerini arttırması beklenmektedir. Dış ticaret hadlerindeki iyileşme, üretimin yönünü ticarete konu olan mallara doğru çevirmektedir. Dolayısıyla dış ticarete konu olan mallar sektöründe ücretlerin artmasına ve genel fiyat seviyesinde bir artışa neden olmaktadır. Bu durum ise yerli para biriminde reel bir değer artışı meydana getirmektedir.

- Verimliliğin artması, yerli para biriminin değer kazanmasına neden olacaktır.

- Net dış varlıklardaki bir artış durumunda, sermaye girişlerinin etkisiyle yerli paraya olan talep artacak ve yerli para birimi değer kazanacaktır.

- Kamu borçlarındaki bir artış risk primini artırmaktadır. Dolayısıyla kamu borç seviyesindeki artış, bir risk göstergesi olarak, yerli para biriminin değerini negatif etkilemelidir. Diğer taraftan artan kamu borcu, ticarete konu olmayan mallara yönelik kamu harcamalarının finansmanında kullanılıyorsa genel fiyat seviyesinin artmasına ve reel döviz kurunun değer kazanmasına neden olacaktır. 
Tablo 2: BEER modeli İçin Birim Kök Testleri

\begin{tabular}{|c|c|c|c|c|c|c|c|c|}
\hline \multirow{3}{*}{$\begin{array}{l}\text { LRER } \\
\text { ADF }\end{array}$} & \multicolumn{4}{|c|}{ Düzey } & \multicolumn{4}{|c|}{ Birinci Fark } \\
\hline & \multirow{3}{*}{$\begin{array}{l}\text { Sabit } \\
-0.9132 \\
-1.3185\end{array}$} & \multirow{3}{*}{$\begin{array}{l}{[0.779]} \\
{[0.618]}\end{array}$} & \multicolumn{2}{|c|}{ Sabit ve Trend } & \multirow{2}{*}{$\begin{array}{l}\text { Sabit } \\
-6.0233\end{array}$} & \multirow[b]{2}{*}[0.0000]{} & \multicolumn{2}{|c|}{ Sabit ve Trend } \\
\hline & & & -2.6761 & [ 0.274] & & & -5.9948 & [0.0000] \\
\hline PP & & & -0.4660 & [ 0.248] & -9.2981 & {$[0.0000]$} & -9.2378 & [0.0000] \\
\hline LTOT & \multicolumn{4}{|c|}{ Düzey } & \multicolumn{4}{|c|}{ Birinci Fark } \\
\hline & \multicolumn{2}{|l|}{ Sabit } & \multicolumn{2}{|c|}{ Sabit ve Trend } & \multicolumn{2}{|l|}{ Sabit } & \multicolumn{2}{|c|}{ Sabit ve Trend } \\
\hline$A D F$ & -2.1003 & [0.245] & -1.5433 & {$[0.806]$} & -6.3495 & [0.0000] & -6.5559 & {$[0.0000]$} \\
\hline PP & -1.7774 & [0.389] & -2.9332 & [0.248] & -14.880 & {$[0.0000]$} & -18.429 & [0.0000] \\
\hline LRER & \multicolumn{4}{|c|}{ Düzey } & \multicolumn{4}{|c|}{ Birinci Fark } \\
\hline & \multicolumn{2}{|l|}{ Sabit } & \multicolumn{2}{|c|}{ Sabit ve Trend } & \multicolumn{2}{|l|}{ Sabit } & \multicolumn{2}{|c|}{ Sabit ve Trend } \\
\hline ADF & -0.8185 & {$[0.808]$} & -3.4487 & [0.051] & -4.9548 & {$[0.0001]$} & -4.9956 & [0.0005] \\
\hline PP & -0.9441 & [0.769] & -3.0083 & [0.135] & -8.9808 & [0.0000] & -8.9776 & [0.0000] \\
\hline NFA & \multicolumn{4}{|c|}{ Düzey } & \multicolumn{4}{|c|}{ Birinci Fark } \\
\hline & \multicolumn{2}{|l|}{ Sabit } & \multicolumn{2}{|c|}{ Sabit ve Trend } & \multicolumn{2}{|l|}{ Sabit } & \multicolumn{2}{|c|}{ Sabit ve Trend } \\
\hline$A D F$ & 0.4055 & [0.982] & -2.4199 & {$[0.366]$} & -5.0896 & {$[0.0000]$} & -5.2198 & [0.0002] \\
\hline PP & -0.9441 & [0.769] & -3.0083 & [0.135] & -8.9808 & {$[0.0000]$} & -8.9776 & [0.0000] \\
\hline LTNT & \multicolumn{4}{|c|}{ Düzey } & \multicolumn{4}{|c|}{ Birinci Fark } \\
\hline & \multicolumn{2}{|l|}{ Sabit } & \multicolumn{2}{|c|}{ Sabit ve Trend } & \multicolumn{2}{|l|}{ Sabit } & \multicolumn{2}{|c|}{ Sabit ve Trend } \\
\hline$A D F$ & -0.8185 & [0.808] & -3.4487 & [0.051] & -4.9548 & [0.0001] & -4.9956 & [0.0005] \\
\hline PP & -0.9441 & [0.769] & -3.0083 & [0.135] & -8.9808 & [0.0000] & -8.9776 & [0.0000] \\
\hline $\bar{R}$ & & & & & & Birin & Fark & \\
\hline & Sabit & & Sabit & Trend & Sabit & & Sabit & Trend \\
\hline ADF & -3.2595 & [0.019] & -6.5110 & {$[0.000]$} & -6.8121 & {$[0.0000]$} & -6.7682 & [0.0000] \\
\hline PP & -3.5229 & [0.009] & -3.7591 & [0.023] & -14.058 & {$[0.0001]$} & -14.989 & [0.0000] \\
\hline
\end{tabular}

- Köşeli parantez içindeki değerler olasılık değerleridir.

BEER modeli aracılığıyla cari yanlış dengelenmenin hesaplanmasından önce serilerin durağanlıkları incelenmiş ve reel faiz oranı farkları serisi hariç tüm değişkenlerin fark durağan olduğu sonucuna ulaşılmıştır. Reel faiz oranları farkı serisi ise seviyesinde durağandır. Elde edilen bu sonuçlar, seriler arasındaki uzun dönem ilişkisinin Johansen eşbütünleşme testi ile sınanmasına olanak tanımamaktadır. Zira Johansen metodu tüm değişkenlerin fark durağan olmasını gerektirmektedir. Dolayısıyla değişkenler arasındaki uzun dönem ilişkisi, seviyesinde durağan ve birinci farkında durağan olan seriler arasındaki uzun dönem ilişkisinin incelenmesine imkân tanıyan, Sınır Testi ve ARDL yaklaşımları ile analiz edilmiştir. 
Tablo 3: BEER Modeli İçin Sınır Testi

\begin{tabular}{lll}
\hline \multicolumn{2}{l}{ Test İstatistiği } & \multicolumn{1}{c}{ k } \\
\hline F-ist & 5.837675 & 3 \\
\hline Kritik Değer Sınırları & \\
\hline Anlamlılık & I(0) Sınırı & I(1) Sınırı \\
$10 \%$ & 2.26 & 3.35 \\
$5 \%$ & 2.62 & 3.79 \\
$1 \%$ & 3.41 & 4.68 \\
\hline
\end{tabular}

Sınır testi sonucunda hesaplanan F istatistiği Peseran vd. (2001: 301-302)'de verilen üst sınır kritik değerlerinden büyük olduğundan, değişkenler arasında eşbütünleşme ilişkisi olmadığı yönündeki $\mathrm{H}_{0}$ hipotezi reddedilmiştir. Dolayısıyla seriler arasında uzun dönem ilişkisi söz konusudur. Sınır testinden elde edilen bu sonuç, seriler arasındaki uzun dönem eşitliğinin ARDL yaklaşımı ile tahmin edilmesine olanak tanımaktadır.

Tablo 4: Kısa Dönem ARDL Eşitliği (BEER Modeli)

\begin{tabular}{|c|c|c|c|c|c|}
\hline Değişken & Katsayı & t- ist. & Değişken & Katsayı & t- ist. \\
\hline $\mathrm{dq}(-1)$ & -0.47529 & -4.53323 & $\operatorname{dnfa}(-5)$ & 0.16217 & 1.35213 \\
\hline$d q(-2)$ & -0.28249 & -2.53928 & $\operatorname{dnfa}(-6)$ & 0.224164 & 1.733877 \\
\hline$d q(-3)$ & -0.35750 & -3.13234 & dgdb & 0.052654 & 7.175099 \\
\hline $\mathrm{dq}(-4)$ & 0.01485 & 0.11329 & $\operatorname{dgdb}(-1)$ & 0.047109 & 4.084454 \\
\hline$d q(-5)$ & -0.01957 & -0.20001 & $\operatorname{dgdb}(-2)$ & 0.024461 & 2.205662 \\
\hline$d q(-6)$ & -0.37557 & -3.83998 & $\operatorname{dgdb}(-3)$ & 0.039293 & 3.913446 \\
\hline dltnt & -0.52453 & -1.92602 & $\operatorname{dgdb}(-4)$ & 0.000758 & 0.072405 \\
\hline dltot & -0.27390 & -1.29209 & $\operatorname{dgdb}(-5)$ & 0.014363 & 1.856036 \\
\hline dltot(-1) & 0.33468 & 1.59563 & $\operatorname{dgdb}(-6)$ & 0.024992 & 3.263183 \\
\hline dltot(-2) & 0.66420 & 2.84364 & $\mathrm{dr}$ & 0.001983 & 2.86434 \\
\hline dltot(-3) & 0.17613 & 0.78495 & $\mathrm{dr}(-1)$ & -0.00246 & -3.07458 \\
\hline dltot(-4) & 0.32828 & 1.47284 & $\mathrm{dr}(-2)$ & -0.00207 & -2.92354 \\
\hline dnfa & 0.18277 & 1.24134 & $\mathrm{dr}(-3)$ & -0.00019 & -0.27913 \\
\hline $\operatorname{dnfa}(-1)$ & 0.38685 & 2.79797 & $\mathrm{dr}(-4)$ & -0.00236 & -3.69302 \\
\hline $\operatorname{dnfa}(-2)$ & 0.52974 & 3.57275 & dd94 & 0.316306 & 7.66213 \\
\hline $\operatorname{dnfa}(-3)$ & 0.53429 & 3.35706 & c & -0.00177 & -0.29091 \\
\hline $\operatorname{dnfa}(-4)$ & 0.23244 & 1.33482 & ecmc(-1) & -0.22880 & -4.99215 \\
\hline
\end{tabular}


Tahmin edilen ARDL modeline ilişkin kısa dönem eşitliği ise Tablo 4'te verilmiştir. Tablo 4'teki sonuçlara bakıldığında hata düzeltme teriminin (ecmc(-1)) negatif işaretli ve istatistiksel olarak anlamlı olduğu görülmektedir. -0.22880 'lik hata düzeltme katsayısı, hata düzeltme mekanizmasının çalıştığını ve t-1 dönemindeki bir şokun etkisinin, yaklaşık \%22'sinin t döneminde ortadan kalktığını ifade etmektedir.

Tablo 5: ARDL $(7,1,5,7,7,5)$ Uzun Dönem Eşitliği (BEER)

\begin{tabular}{|c|c|c|c|c|c|}
\hline Değişken & Katsayı & t- ist. & Değişken & Katsayı & t- ist. \\
\hline Irer(-1) & 0.198638 & 1.636511 & $\mathrm{nfa}(-5)$ & -0.217110 & -1.186774 \\
\hline Irer(-2) & 0.159190 & 1.216118 & $\mathrm{nfa}(-6)$ & 0.078083 & 0.427899 \\
\hline Irer(-3) & -0.044587 & -0.314205 & $\mathrm{nfa}(-7)$ & -0.256575 & -1.728602 \\
\hline Irer(-4) & 0.311431 & 1.868649 & gdb & 0.052073 & 6.690827 \\
\hline Irer(-5) & 0.060510 & 0.385496 & $\operatorname{gdb}(-1)$ & -0.021395 & -1.684185 \\
\hline Irer(-6) & -0.375991 & -2.377714 & $\operatorname{gdb}(-2)$ & -0.022832 & -1.654207 \\
\hline Irer(-7) & 0.411361 & 3.734609 & $\operatorname{gdb}(-3)$ & 0.012644 & 0.911251 \\
\hline Itnt & -0.463620 & -2.566762 & $\operatorname{gdb}(-4)$ & -0.036296 & -2.650400 \\
\hline Itot & -0.297887 & -1.215537 & $\operatorname{gdb}(-5)$ & 0.007524 & 0.573376 \\
\hline Itot(-1) & -0.134409 & -0.469241 & $\operatorname{gdb}(-6)$ & 0.011981 & 0.975563 \\
\hline Itot(-2) & 0.461224 & 1.618092 & $\operatorname{gdb}(-7)$ & -0.029296 & -3.636546 \\
\hline Itot(-3) & -0.575375 & -1.956199 & $r$ & 0.002262 & 2.561522 \\
\hline Itot(-4) & 0.216934 & 0.735579 & $r(-1)$ & -0.000401 & -0.393367 \\
\hline Itot(-5) & -0.442755 & -1.782847 & $r(-2)$ & 0.000632 & 0.612637 \\
\hline nfa & 0.089658 & 0.624280 & $r(-3)$ & 0.001752 & 1.733081 \\
\hline$n f a(-1)$ & 0.093288 & 0.440810 & $r(-4)$ & -0.001709 & -1.908240 \\
\hline$n f a(-2)$ & 0.170832 & 0.820542 & $r(-5)$ & 0.002360 & 3.232073 \\
\hline$n f a(-3)$ & 0.023598 & 0.111148 & d94 & 0.281715 & 6.392131 \\
\hline$n f a(-4)$ & -0.215075 & -1.041208 & c & 0.333608 & 3.459329 \\
\hline
\end{tabular}

Eşbütünleşme ve kısa dönem eşitliğinin ardından tahmin edilen uzun dönem eşitliği Tablo 5 'te verilmiştir. Bu aşamada tahmin edilen ARDL eşitliğinin uygunluğunu sınamak için, modelden elde edilen artık terimlerin sabit varyans, normal dağılım ve ardışık bağımsızlığa yönelik bir takım varsayımları sağlayıp sağlamadığı test edilmiştir. 
Tablo 6: ARDL $(7,1,5,7,7,5)$ Modeline Ait Tanılayıcı Testler

\begin{tabular}{|c|c|c|c|}
\hline \multicolumn{4}{|c|}{ Breusch - Godfrey Serial Otokorelasyon LM test } \\
\hline F-ist. & 0.538929 & Prob. $F(2,45)$ & 0.5871 \\
\hline$N^{*} R^{2}$ & 1.988328 & Prob. Chi-Square(2) & 0.3700 \\
\hline \multicolumn{4}{|c|}{ White Heteroskedastisite Testi } \\
\hline F-ist & 0.547361 & Prob. $F(37,47)$ & 0.9699 \\
\hline$N^{*} R^{2}$ & 25.59689 & Prob. Chi-Square(37) & 0.9212 \\
\hline \multicolumn{4}{|c|}{ Ramsey Reset Test } \\
\hline F-ìst & 0.035413 & Olasılık & 0.9652 \\
\hline \multicolumn{4}{|c|}{ Jarque-Bera Normal Dağılım Testi } \\
\hline JB ist. & 1.553776 & Olasılık & 0.4598 \\
\hline
\end{tabular}

Tablo 6'da verilen tanılayıcı testler, ARDL $(7,1,5,7,7,5)$ modelinde otokorelasyon, değişen varyans, yanlış fonksiyonel form seçimi gibi problemlerin olmadığını ve modelden elde edilen hata terimlerinin normal dağıldığını göstermektedir. Bununla birlikte, modelin uygunluğunun sınanması için tanılayıcı testlerin yanında, eşitliklerden elde edilen katsayıların istikrarının da test edilmesi gerekmektedir. Zira eşbütünleşme ilişkisinin varlığı modelden elde edilen katsayıların istikrarını garanti etmemektedir. Bu nedenle, modelden elde edilen artık terimlere, CUSUM ve CUSUMSQ testleri uygulanarak, uzun dönem katsayılarının istikrarı sınanmıştır.

Grafik 1: CUSUM ve CUSUMSQ Testleri Sonuçları (BEER Modeli)

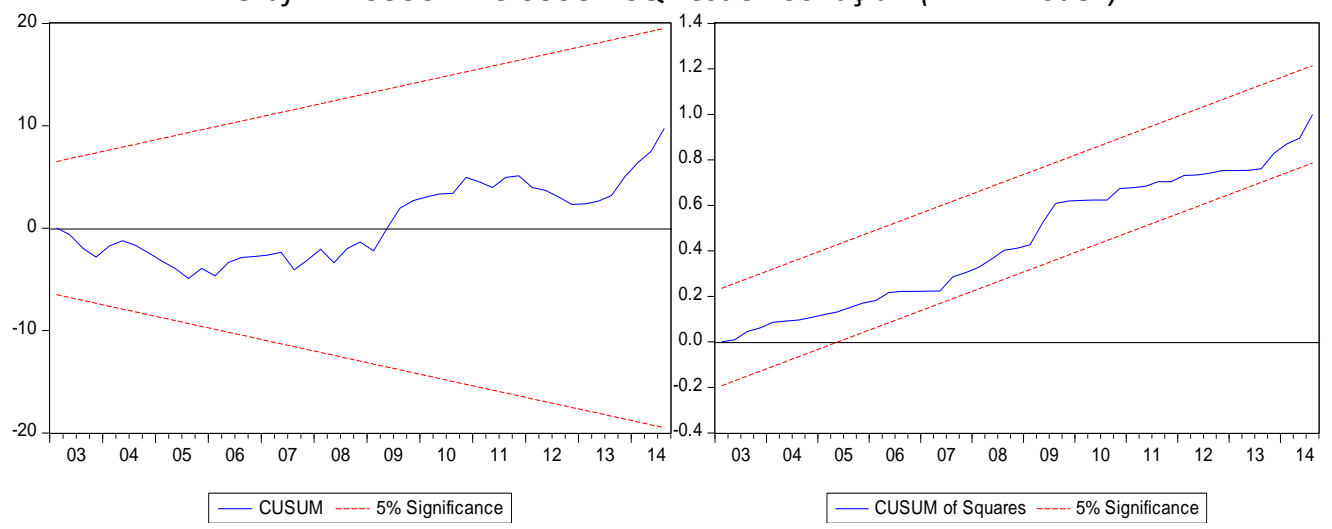

Grafik 1'de verilen CUSUM ve CUSUMSQ testi sonuçlarına göre, her iki teste ait test istatistiklerinin kritik değerler arasında kaldığı görülmektedir. Dolayısıyla uzun dönem katsayıları istikrar koşulunu sağlamaktadır. 
Tablo 7: ARDL Modeli Uzun Dönem Katsayıları (BEER)

\begin{tabular}{lrc}
\hline Değişken & Katsayı & $\mathrm{t}$ - istatistiği \\
LTNT & -1.659062 & -3.007675 \\
LTOT & -2.763553 & -2.996284 \\
NFA & -0.834864 & -1.988716 \\
GDB & -0.091603 & -3.972330 \\
R & 0.017518 & 2.240172 \\
C & 1.193814 & 5.361077 \\
\hline
\end{tabular}

ARDL eşitliğinden elde edilen sonuçlara göre, tüm değişkenler istatistiksel olarak anlamlıdır. Ayrıca dış borç stoku ve faiz oranı farkları haricinde tüm değişkenlerin işaretleri beklentilerle uyumludur. Modelde değişkenlere ait negatif bir katsayı TL'nin reel olarak değer kazandığını ifade etmektedir. Esasen modele risk faktörü olarak dâhil edilen net dış borç stokunun reel döviz kurunda bir değerlenmeye, yani TL'de bir değer kaybına neden olması beklenmektedir. Ancak Türkiye'de Çulha vd. (2008)'de de belirtildiği gibi, kamu açıklarının talep ve fiyatları uyarıcı etkisinin, risk algılamalarının üzerinde bir etki yarattığı görülmektedir. Faiz oranı farklarındaki bir artışın ise, sermaye girişlerini uyararak, TL'nin değer kazanmasıyla sonuçlanması beklenmektedir. Fakat faiz oranı farklarına dair katsayının pozitif işaretli olması, faiz oranı farklarındaki bir artışın TL'nin değer kaybetmesine neden olduğunu göstermektedir. Bu durum ise örtük olmayan faiz paritesi koşulunun tuttuğunu göstermektedir. Zira örtük olmayan faiz paritesi koşuluna göre, yüksek faiz oranına sahip ülke para biriminin, arbitraj imkânları ortadan kalkana kadar değer kaybetmesi beklenmektedir. Sonuç olarak, modelden elde edilen tüm katsayılar istatistiksel olarak anlamlı ve reel döviz kuru üzerindeki etkileri teoriyle tutarlıdır. Ayrıca yapılan tanılayıc testler de, modelin herhangi bir varsayımı ihlal etmediğini göstermektedir. Dolayısıyla yanlış dengelenmenin ölçülmesi için bu modelin kullanılması uygundur.Bu aşamada, BEER modeli ile cari yanlış dengelenmenin elde edilmesi için öncelikle uzun dönem katsayıları ile değişkenlerin cari değerleri çarpılarak BEER hesaplanmaktadır. Daha sonra, reel döviz kurunun cari değerlerinden, temel makro değişkenlerin cari değerleri için hesaplanan reel döviz kuru (BEER) çıkarılarak, cari yanlış dengelenmeye ulaşılmaktadır.

\section{Grafik 2: Cari Yanlış Dengelenme}

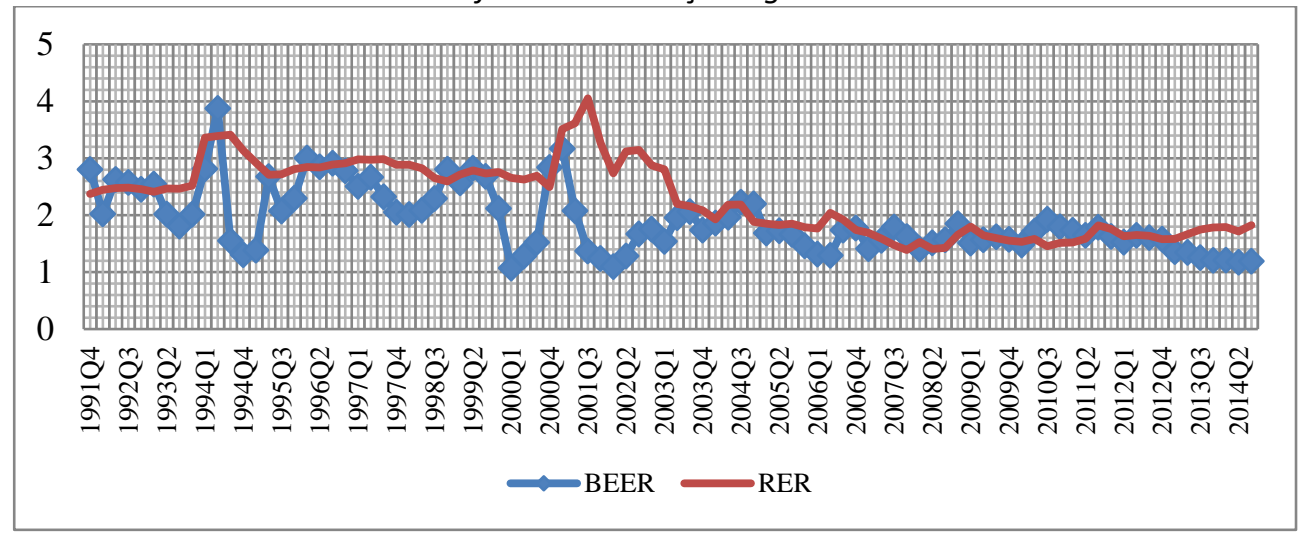


BEER ve cari reel döviz kurunun seyri Grafik 2'de verilmiştir. 1991-1994 yılları arasında, genel olarak TL'nin aşırı değerli olduğu görülmektedir. Bu durumun nedeni, 1989 yılı ile birlikte, Türk Lirasının konvertibilitesinin artırılmasına ve sermaye hareketlerinin serbestleşmesine yönelik düzenlemelerin ardından, yüksek faiz oranlarının da etkisiyle artan kısa vadeli sermaye girişlerine yerinde müdahale edilememesidir. Ancak 1993 yılının ikinci çeyreğinden itibaren TL, Dolar karşısında değer kaybetmeye başlamıştır. 1994 Ocak ayında hükümetin faizleri düşürme çabasıyla başlayan ve 1994 Nisan ayında meydana gelen krizin ardından ise TL dolar karşısında reel olarak sert bir değer kaybı yaşamıştır.

1994 Ocak ayında krizin meydana gelmesinden hemen önce, Türk Lirasının değeri \%14 oranında düşürülmüş, ancak krizin ortaya çıkması ile birlikte Türk Lirası reel olarak \%70 değer kaybetmiştir (Özçam, 2004: 10). Bu dönemde, TL'de meydana gelen reel değer kaybı Grafik 3'te de net bir şekilde görülmektedir. Daha önce de belirtildiği gibi, krizin meydana gelmesi ile birlikte \%70'e varan bir reel değer kaybı yaşanırken, BEER modelinin, dolayısıyla temel makro değişkenlerin cari seviyelerinin, öngördüğü seviyeden ise \%140'a varan bir sapmanın gerçekleştiği görülmektedir.

Krizin ardından, 1995-2000 yılları arasında zaman zaman aşırı değerlenmeler ve eksik değerlenmeler meydana gelmiştir. 1995 yılından itibaren TCMB'nin kur politikası kuru belirli bir seviyede tutmaya yönelik, daha katı bir müdahale şeklinde yön değiştirmiştir. 1995-1999 yılları arasında TL'nin değerinin, enflasyondaki artış oranında düşürüldüğü bir strateji izlenmiştir. Grafik 2 ve Grafik 3'te de görüldüğü üzere, bu dönemde 1997 Güneydoğu Asya krizi ve 1998 Rusya krizine rağmen reel döviz kurunda ciddi bir yanlış dengelenme söz konusu olmamıştır. Bu durumun nedeni, TCMB'nin 1997 yılından itibaren reel kur endekslerindeki dalgalanmayı en aza indirgemeye yönelik politikalar uygulamasıdır (TCMB, 1998). 1999 yılında yaşanan iki büyük deprem felaketi ardından ise IMF ile yeni bir ekonomik program hazırlanmış ve bu program çerçevesinde, 2000 Kasım ayına kadar kurlardaki artışın önceden belirlendiği ve ilan edildiği bir kur politikası izlenmiştir (TCMB, 2001: 72).

\section{Grafik 3: BEER Modeli Cari Yanlış Dengelenmenin Boyutu (\%)}

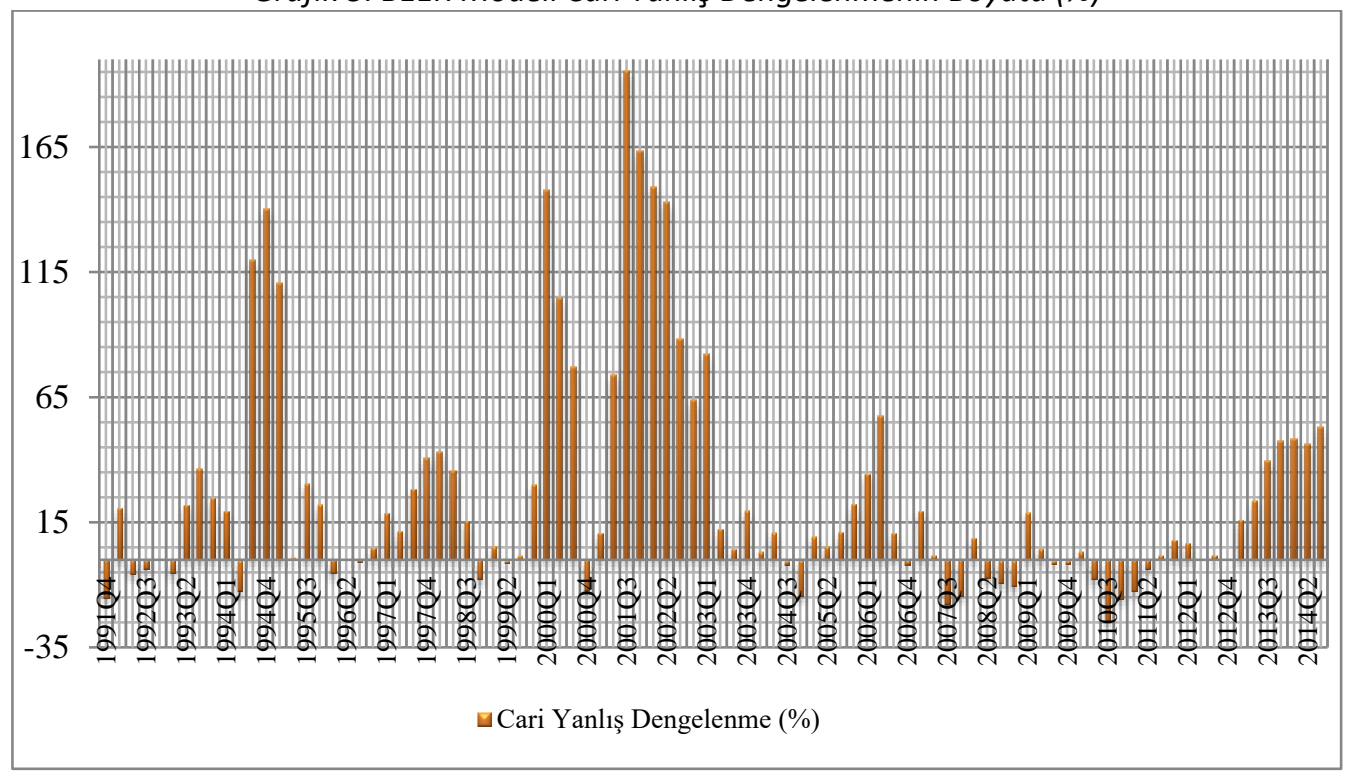


Uygulanan gerçekçi olmayan kur politikasının, 2000 yılı genelinde TL'nin reel değeri üzerindeki yansıması Grafik 2 ve 3'te görülmektedir. Ancak yapısal reformların gecikmesi, devlet iç borçlanma senetleri faizlerinin artması ve BDDK'nın bir bankaya el koyması üzerine, 2000 Kasım ayında meydana gelen sarsıntı, hükümet tarafından alınan ek önlemler ve IMF'den alınan ek kredi ile bastırılmasına rağmen, 2001 Şubat ayında yeni ve daha büyük bir krizin meydana gelmesine neden olmuştur (TCMB, 2001; Özçam, 2004: 12).

2001 yılında meydana gelen krizin ardından, serbest dalgalı kur rejimine geçilmesinin reel döviz kuru üzerindeki etkisi oldukça büyük olmuştur. Türk Lirası, 2001 yılının ilk çeyreğinde ABD doları karşısında reel olarak ani bir değer kaybı yaşamış, ancak 2001 yılının ikinci çeyreğinde bu değer kaybı zirve noktasına ulaşmış ve BEER'in öngördüğü denge reel döviz kurundan sapmanın boyutu \%195'e ulaşmıştır. 2003 yılının 2. çeyreğine kadar, BEER'den sapmanın boyutu \%80'lerin altına inmemiştir.

2001 krizinin ardından Türkiye'de kurlar serbest dalgalanmaya bırakılarak, 2002-2005 yılları arasında örtük, 2006 yılı ve sonrasında ise açık enflasyon hedeflemesi stratejisi uygulanmaya başlanmıştır. 2006 yılından itibaren uygulanan ve hali hazırda uygulanmaya devam eden bu yeni para politikası stratejisi ile birlikte, 2001 krizi ardından para politikasını bağımsız olarak yönetme yetkisi kazanan merkez bankası, kurlar üzerinde herhangi bir hedef belirlememektedir. Dolayısıyla döviz kuru, piyasa güçleri tarafından belirlenmektedir. Grafik 11 ve 12 'ye bakıldı̆̆ında serbest dalgalanan kur rejimine geçişle birlikte yanlış dengelenmenin nispeten azaldığı görülmektedir. Serbest dalgalı kur rejiminde, kurlar üzerinde bir hedefin olmaması ve kurların piyasa güçleri tarafından belirlenmesi, reel döviz kurunun temel makro değişkenlerin öngördügü denge seviyesine yaklaşmasını sağlamıştır. Ancak örtük enflasyon hedeflemesi stratejisinin uygulandığı 2002-2005 dönemine kıyasla, açık enflasyon hedeflemesi stratejisinin uygulanmaya başlandığı 2006 yılı ve sonrasında, reel döviz kurunun denge seviyesinden sapmalarının daha büyük olduğu gözlenmektedir. 2006 yılında reel döviz kuru, denge seviyesinden \%57'ye varan bir sapma göstermiş ve TL reel olarak değer kaybetmiştir.

2006 yılı TL'nin eksik değerlendiği bir dönem olurken, 2007-2012 yılları arasında TL'de bir aşırı değerlenme probleminden bahsetmek mümkündür. 2007 yılının 3. çeyreğinden itibaren başlayan aşırı değerlenme, 2012 yılı başlarına kadar devam etmiştir. Bu dönemde hem TCMB'nin yüksek kur düşük faiz politikası hem de ABD'de başlayan ve dünyanın geri kalanına yayılan finansal krizin etkisiyle TL'de aşırı değerlenme problemi ortaya çıkmıştır. ABD merkez bankası, küresel boyut kazanan krizden kurtulmak ve ekonomiyi yeniden canlandırmak amacıyla, ciddi boyutta parasal genişlemeye giderek faizleri düşürmüştür. Dünyanın geri kalanında da, merkez bankaları yaşanan likidite sıkıntısının önüne geçmek ve ekonomileri durgunluktan çıkarmak amacıyla faiz oranlarının düşürülmesine yönelik politikalar uygulamışlardır.

Bu dönemde, düşük kur ve yüksek faiz stratejisi uygulayan TCMB de diğer merkez bankaları gibi, ekonominin canlanması amacıyla, politika faiz oranlarını düşürmüştür. Bununla birlikte, olumsuz küresel koşullar nedeniyle 2008 yılında TCMB, yabancı para likiditesinin daralmaması ve finansal piyasalarda meydana gelebilecek sorunların önüne geçmek amacıyla döviz alım ihalelerini durdurmuştur. Böylelikle döviz piyasasındaki likiditenin sistemde kalması sağlanmıştır. 2009 yılında \%-4.7'lik bir ekonomik büyüme rakamına rağmen, hane halkının döviz cinsinden borçlanma seviyesinin düşük olması ve 2001 krizi ardından yapılan yapısal reformlar dolayısıyla daha güçlü bir finansal yapının var olması nedeniyle Türkiye'nin risk primindeki bozulma sınırlı düzeyde kalmıştır. Ağustos 2009'da küresel ekonomiye dair olumlu gelişmeler ve artan likidite dolayısıyla Türkiye ve diğer gelişmekte olan ülkelere olan sermaye akımlarının da artmasıyla TL, ABD doları karşısında değer kazanmaya başlamıştır (TCMB, 2009: 15). Bu dönemde gelişmişülke 
merkez bankalarının parasal genişleme politikaları, Türkiye ve gelişmekte olan diğer ülkelerde kısa vadeli yurtdışı finansman imkânlarını arttırmış ve finansal istikrarın bozulmasına yol açacak riskler doğurmuştur. Bu nedenle, 2001 yılından itibaren tek nihai hedefi olan TCMB, 2010 yılının son çeyreğinden itibaren finansal istikrarı sağlamaya yönelik politikalar da geliştirmek durumunda kalmıştır. Bu bağlamda, faiz koridoru ile bir yandan kısa vadeli sermaye girişlerini kontrol altına almayı hedeflerken, diğer yandan TL'deki aşırı değerlenmenin önlenmesini hedeflemiştir. Ayrıca kısa vadeli sermaye akımlarının, merkez bankasının döviz rezervlerini arttıracak şekilde değerlendirilmesi amacıyla, düzenli olarak döviz alım ihaleleri açılmıştır. Sonuç olarak, alınan önlemler ile birlikte TL'nin aşırı değerlenmesinin önüne geçilmiştir (TCMB, 2011: 3). Uygulanan politikalar sonucunda 2011 yılı 3. çeyreğinden itibaren TL'deki reel aşırı değerlenmenin de önüne geçildiği Grafik 12'de görülmektedir. 2011 yılının 3. çeyreğinde reel döviz kurunun, denge seviyesinden yalnızca \%1.8'lik bir sapma gösterdiği görülmektedir. Takip eden dönemlerde ise TL ABD doları karşısında reel olarak yeniden eksik değerlenme sürecine girmiştir. Ancak 2013 yııının ilk çeyreğine kadar yanlış dengelenme oldukça sınırlı boyutta seyretmiştir.

2013 Mayıs ayı sonrasında, küresel finansal koşullarda meydana gelen değişmeler ve küresel risk iştahının azalması sonucunda, Türkiye ve diğer gelişmekte olan ülkelere olan kısa vadeli sermaye akımları dışarı yönlü gelişmiştir. Bu durum TL'de belirgin bir değer kaybına neden olmuştur (TCMB, 2014: 3). Aynı dönemde, Türkiye'de yaşanan siyasi çalkantılar da, uluslararası kısa vadeli sermaye girişlerini olumsuz yönde etkileyerek, TL'nin değer kaybetmesine neden olan bir diğer faktör olmuştur. Grafik 4'te de görüldüğü üzere, TL, 2013 ve 2014 yılları arasında genel olarak reel manada değer kaybetmiş ve yanlış dengelenmenin boyutu 2014 yılında $\% 52$ 'lere yükselmiştir.

\section{Grafik 4: Toplam Yanlış Dengelenme}

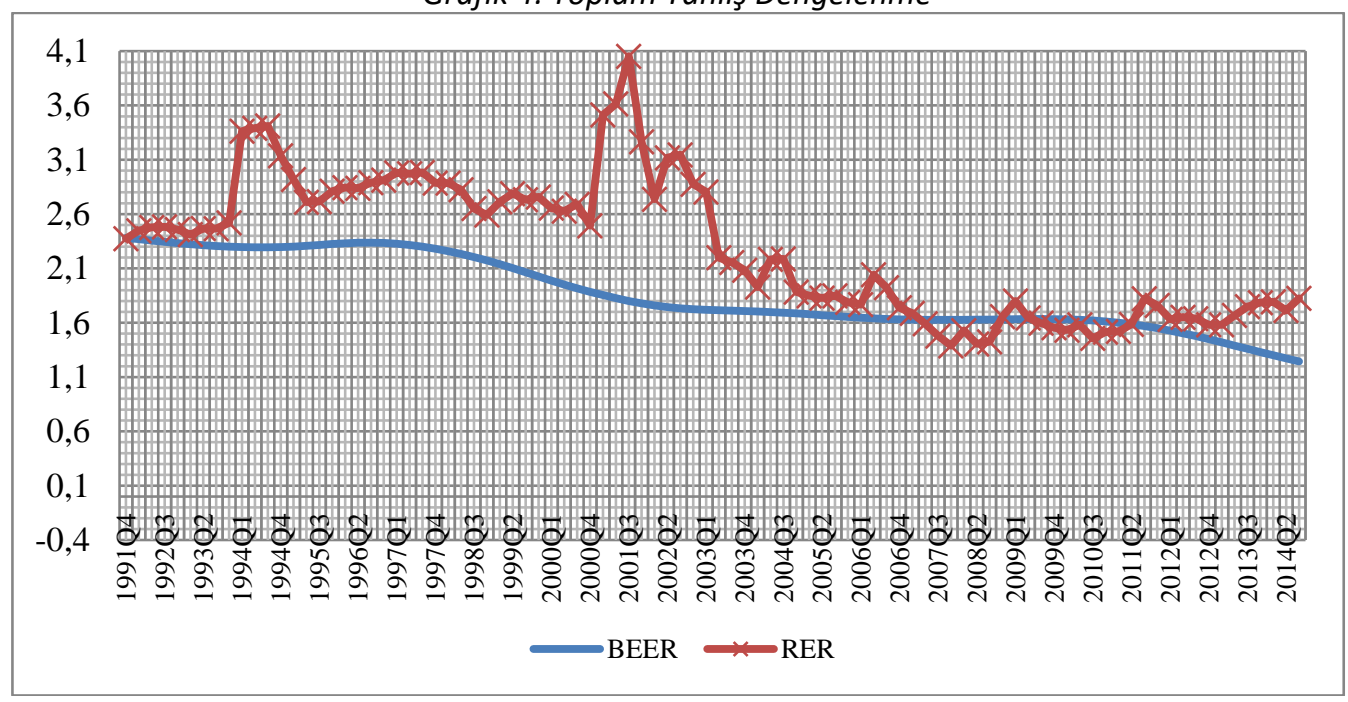

BEER modeli çerçevesinde cari yanlış denglenemenin elde edilmesinin ardından ikinci aşamada reel döviz kurunun uzun dönem denge seviyesinden ne kadar saptığını gösteren toplam yanlış dengelenme ölçülmüştür. Toplam yanlış denglenmenin ölçülmesi için öncelikle HodrickPrescott filtresi ile temel makro değişkenlerin uzun dönem değerleri ayrı ayrı elde edilmiştir. Daha sonra, ARDL modelinden elde edilen uzun dönem katsayıları ile temel makro değişkenlere 
ait, bu uzun dönem denge değerleri çarpılarak, uzun dönem BEER elde edilmiştir. Bunun ardından ise reel döviz kurunun gerçek değerlerinden uzun dönem BEER çıkarılarak toplam yanlış dengelenme elde edilmiştir.

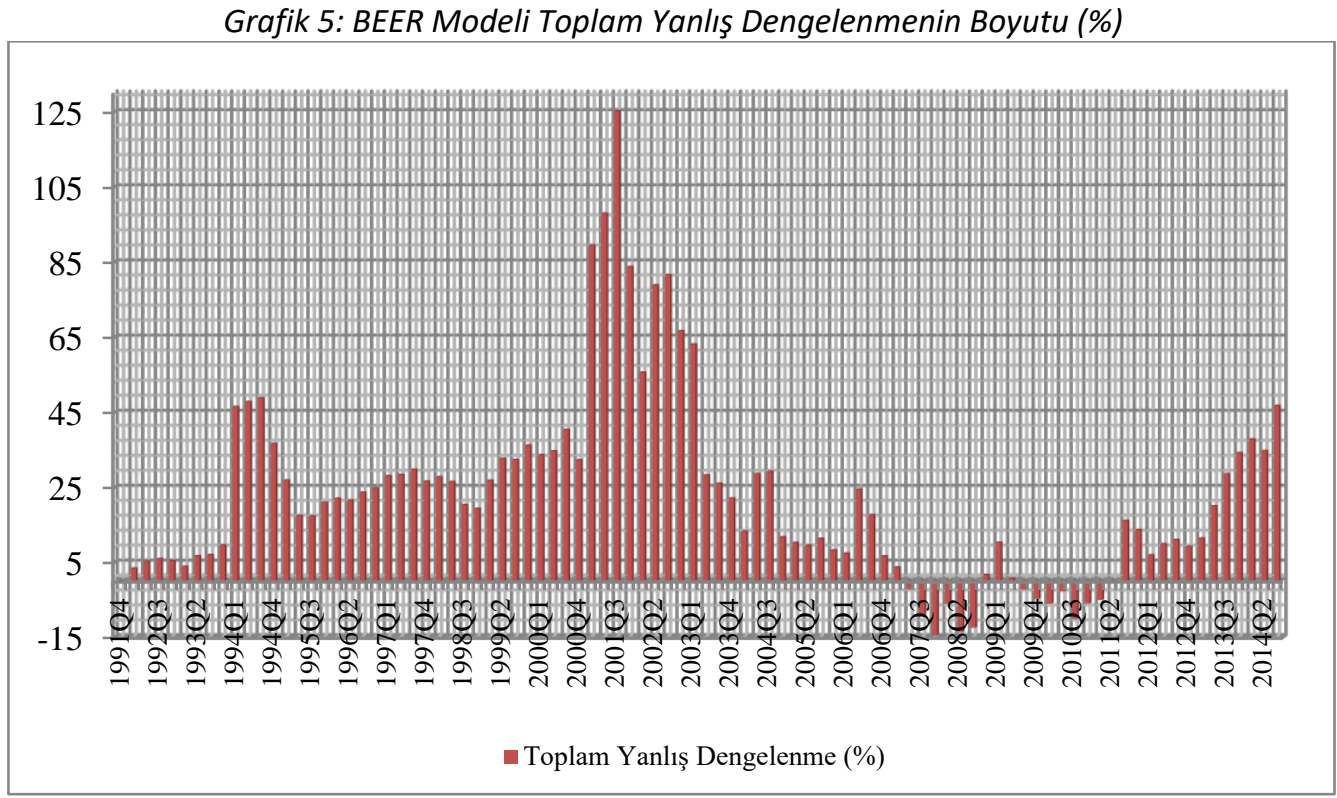

BEER modeli ile elde edilen toplam yanlış dengelenme Grafik 5'te verilmiştir. Grafik 13'e göre Türk Lirası Amerikan Doları karşısında 1990'lı yılların başlarından 2007 yılına kadar, reel olarak eksik değerlenmiştir. Yani Türk Lirası, makroekonomik değişkenlerin uzun dönem değerlerinin öngördügü, uzun dönem denge seviyesinin oldukça altında seyretmiştir. 90’lı yılların başından, 2001 krizine kadar, genellikle sabit kur rejimleri ile döviz kuru baskı altında tutulmuştur. Buna rağmen, TL bu dönemde dahi, reel olarak uzun dönem denge seviyesinin altında değerlenmiştir. Türkiye ekonomisinde meydana gelen iki büyük kriz olan 1994 ve 2001 krizleri TL'nin reel değerinde sert düşüşlere neden olurken, 2007 yılı ilk çeyreğinden itibaren TL, Amerikan Doları karşısında aşırı değerlenmiş ve 2011 yılının üçüncü çeyreğine kadar genel olarak, uzun dönem denge seviyesinin üzerinde seyretmiştir. Bu dönemde yalnızca, 2008 küresel finansal krizinin etkisiyle, 2008 yılının son çeyreğinden, 2009 yılının 2. çeyreğine kadar ABD doları karşısında reel manada değer kaybeden TL, 2011 son çeyreğinden itibaren genel olarak eksik değerlenme sürecine girmiştir.

Grafik 14'e bakıldığında, TL'deki toplam yanlış dengelenme daha net bir şekilde görülmektedir. Analize konu olan dönemde, TL/Dolar reel kurundaki toplam yanlış dengelenmenin boyutu ortalama \%22.5 oranında seyretmiştir. Yani TL, ABD doları karşısında, BEER'in öngördüğü denge seviyesinden, ortalama \%22.5 eksik değerlenmiştir. Yanlış dengelenmenin boyutu; 1994 krizi ile birlikte \%49'lara ulaşırken, 2001 krizi ile birlikte \%125'lik bir yanlış dengelenme meydana gelmiştir. Ancak burada dikkati çeken en önemli nokta; 2014 yılı 3. çeyreğinde, herhangi bir kriz dönemi olmamasına rağmen, yanlış dengelenmenin boyutunun \%46 ile 1994 krizi dönemine oldukça yaklaşmış olmasıdır. 


\section{Sonuç}

Döviz kuru, bir ülkenin küresel ekonomi ile bağlarını temsil eden önemli bir göstergedir. Ticarete konu olan ve olmayan malların nispi fiyatını belirleyen reel döviz kuru ise bir yandan ülkenin dış rekabet gücünü temsil ederken diğer taraftan, ekonominin işleyişi içerisinde, kaynak transferleri ve faktör hareketleri açısından bir sinyal rolü üstlenmektedir. Bu nedenle, reel döviz kurlarının yanlış dengelenmesi, ekonomik birimlerin tüketim ve üretim faaliyetlerini yürütürken karar alma süreçlerinde bozulmalara yol açabilen, dış rekabet gücünü zayıflatan ve bu bağlamda, ekonomi açısından maliyeti oldukça yüksek olan bir problemdir.

Reel döviz kurlarındaki olası bir kalıcı aşırı değerlenme, ülkeleri spekülatif ataklara ve para krizlerine açık hale getirmektedir. Diğer taraftan reel eksik değerlenme, ekonominin aşırı ısınmasına, dolayısıyla yurtiçi fiyatlar üzerinde baskı oluşmasına ve kaynakların ticarete konu olan ve olmayan mallara ilişkin sektörler arasında yanlış dağılmasına neden olmaktadır. Bununla birlikte, reel döviz kurlarının eksik değerlenmesinin ise ekonomik büyümeyi desteklediği yönünde bir görüş birliği söz konusudur. Bu nedenle, bu çalışmada 2000'li yılların başlarında kura dayalı bir istikrar politikası yürütürken büyük bir kriz yaşayan Türkiye ekonomisi için denge reel döviz kurunun elde edilmesi ve yanlış dengelenmenin ölçülmesi amacıyla davranışsal denge döviz kuru modeli tahmin edilmiştir. Modelin tahmininde 1991Q1-2014Q3 dönemini kapsayan çeyreklik veriler kullanılmıştır.

BEER modelinden elde edilen sonuçlara göre, 1991 yılı dördüncü çeyreği ile 2014 yılı 4.çeyreği arasında genel olarak Türkiye' de reel döviz kurunun uzun dönem denge seviyesinin altında değerlendiğini söylemek mümkündür. Dolayısıyla Türkiye için reel döviz kurunda bir eksik değerlenme problemi olduğunu söylemek mümkündür. Bununla birlikte BEER modelinden elde edilen sonuçlara göre reel döviz kurlarında, cari denge seviyesine göre, kısa süreli aşırı değerlenmeler de meydana gelmiştir. Ayrıca Türkiye'de sabit veya yarı esnek kur rejimlerinin uygulandığı dönemlerde reel döviz kurlarının denge seviyesinden sapma boyutunun oldukça yüksek seviyelerde seyrettiği görülmektedir. Serbest dalgalanan döviz kuru rejiminin uygulandığı dönemlerde ise reel döviz kurları denge seviyesine yakınsamaktadır. Bu durum Merkez Bankasının kur politikası açısından da önemli çıkarımlar yapılmasına olanak tanımaktadır. Zira elde edilen bulgulara göre Türkiye ekonomisinin performansı açısından serbest dalgalı döviz kuru rejiminin tercih edilmesi olumlu sonuçlar doğuracaktır. Ayrıca uygulanan sabit veya yarı esnek kur rejimlerinin, TL'nin reel olarak aşırı değerlenmesine yol açtığı, aşırı değerlenmenin ise krizlere yol açtığını söylemek mümkündür. Zira davranışsal denge döviz kuru modelinden elde edilen sonuçlara göre 1991Q4-1993Q2 ve 1996Q1-1999Q3 dönemlerinde, Türkiye ekonomisinde meydana gelen en büyük krizler olan 1994 ve 2000-2001 krizlerinden hemen önce TL'nin aşırı değerli olduğu görülmektedir.

Açıklamalar ve bulgulardan hareketle reel döviz kurlarının yanlış dengelenmesinin, meydana gelebilecek krizlere zemin hazırladığını söylemek mümkündür. Diğer taraftan reel döviz kurunun, serbest dalgalı döviz kuru rejiminin uygulandığı dönemde denge seviyesine yakınsadığı görülmektedir. Bu durumun para politikası açısından önemi ise bir bakıma para politikası bağımsızlığına kavuşma imkânının doğmasıdır. Zira imkânsız üçleme hipotezine göre, sermaye hareketlerini serbest bırakan bir ülkede, politika yapıcılar, döviz kuru istikrarı ve bağımsız bir para politikası arasında seçim yapmak zorundadırlar. Bu açıdan değerlendirildiğinde Türkiye'de serbest dalgalı döviz kuru rejiminin uygulanması ile birlikte para politikası bağımsızlığından ödün verilmesine gerek kalmamış ve uzun yıllar boyunca Türkiye ekonomisinin gündemindeki en önemli sorun olan, kronik enflasyon probleminin üstesinden gelinebilmesi için, enflasyon hedeflemesi stratejisinin uygulamaya konulmasına yönelik bir imkân doğmuştur. 


\section{Kaynaklar}

Clark, P. B. and R. MacDonald (1997), "Exchange Rates And Economic Fundamentals: A Methodological Comparison of BEERS and FEERS", (Ed. R. MacDonald ve J.L. Stein), Equilibrium Exchange Rates, Kluwer Academic Publishers, Londra: Birleşik Krallık: 285-322.

Clark, P.B. ve R. MacDonald (1999), "Exchange Rates And Economic Fundamentals: A Methodological Comparison of BEERS and FEERS", (Ed: R. MacDonald ve J.L. Stein), Equilibrium Exchange Rates, Kluwer Academic Publishers, Londra: Birleşik Krallık:285-322.

Clark, P.B. ve R. MacDonald, (1998). “Exchange Rates and Economic Fundamentals: A Methodological Comparison of BEERS and FEERS", International Monetary Fund Working Paper No. 98/67.

Clark, P.B. ve R. MacDonald (2000), "Filtering The BEER: A Permanent and Transitory Decomposition", International Monetary Fund, Working Paper No. 00/144.

Çulha, O; Çulha, A. ve Gönenç, R. (2008), “The Challenges of Monetary Policy in Turkey”, OECD Economic Department Working Paper No: 646.

Edwards, S. (1987), "Exchange Rate Misalignment in Developing Countries", Los Angeles: University of California and National Bureau of Economic Research.

Edwards, S. (1988), "Real and Monetary Determinants of Real Exchange Rate Behavior", Journal of Development Economics, Vol. 29: 311-341.

Edwards, S. (1989), "Real Exchange Rates, Devaluation and Adjustment: Exchange Rate Policy in Developing Countries", Cambridge, Mass and London: MIT Press.

Edwards, S. (1994), "Real and Monetary Determinants of Real Exchange Rate Behavior: Theory and Evidence From Developing Countires", (Ed. J. Williamson), Estimating Equilibrium Exchange Rates, Washington DC: Institute for International Economics: 61-92.

Elbadawi, I.A. (1994), “Estimating Long-Run Equilibrium Real Exchange Rates”, (Ed. J. Williamson), Estimating Equilibrium Real Exchange Rates, Londra: Longman Group Limited.

MacDonald, R. (2007), “Exchange Rate Economics: Theories and Evidence”, NewYork: Routledge.

MacDonald, R. ve Dias, P. (2007), "Behavioural Equilibrium Exchange Rate Estimates and Implied Exchange Rate Adjustments for Ten Countries", Workshop on Global Imbalances, Peterson Institute of International Economics, Washington DC, February 2007.

Özçam, M. (2004), “Döviz Kuru Politikaları ve Türkiye'de Döviz Kuru Oynaklığının Etkileşimleri”, SPK Araştırma Raporu. http://www.spk.gov.tr/yayingoster.aspx?yid=943\&ct =f\&action=displayfile. (Erişim: 10.11.2015).

Pesaran, M. H.; Shin, Y. and Smith, R. J. (2001), "Bounds Testing Approaches to The Analysis of Level Relationships", Journal of Applied Econometrics, Vol.16: 289-326.

TCMB, (1998), "Merkez Bankası 1998 Yılı Illk Altı Aylık Para Programı Gerçekleşmesi Ve İkinci Altı Aylık Para Politikası Uygulaması".

TCMB, (2001), "Para Politikası Raporu”.

TCMB, (2009), "2010 Yılında Para ve Kur Politikası".

TCMB, (2011), "2012 Yılında Para ve Kur Politikası".

TCMB, (2014), "2015 Yılında Para ve Kur Politikası". 
Eskişehir Osmangazi Üniversitesi iiBF Dergisi

112 